\title{
PALEO
}

Revue d'archéologie préhistorique

$24 \mid 2013$

Varia

\section{A map and a database for flint-bearing formations in Southern France: A tool for Petroarchaeology}

Une carte et une base de données pour les formations à silex du sud de la

France: un outil pour la pétroarchéologie

Paul Fernandes, Jean-Paul Raynal, Pascal Tallet, Christophe Tuffery, Michel Piboule, Micheline Séronie-Vivien, Marie-Roger Séronie-Vivien, Alain Turq, André Morala, Jehanne Affolter, Dominique Millet, Françoise Millet, Fréderic Bazile, Patrick Schmidt, Pascal Foucher, Vincent Delvigne, Jérémie Liagre, Stéphane Gaillot, Alexandre Morin, Marie-Hélène Moncel, Jean-François Garnier and Céline Léandri-Bressy

\section{(2) OpenEdition}

Electronic version

URL: http://journals.openedition.org/paleo/2864

DOI: $10.4000 /$ paleo.2864

ISSN: 2101-0420

Publisher

SAMRA

Printed version

Date of publication: 15 December 2013

Number of pages: $219-228$

ISSN: $1145-3370$

Electronic reference

Paul Fernandes, Jean-Paul Raynal, Pascal Tallet, Christophe Tuffery, Michel Piboule, Micheline Séronie-Vivien, Marie-Roger Séronie-Vivien, Alain Turq, André Morala, Jehanne Affolter, Dominique Millet, Françoise Millet, Fréderic Bazile, Patrick Schmidt, Pascal Foucher, Vincent Delvigne, Jérémie Liagre, Stéphane Gaillot, Alexandre Morin, Marie-Hélène Moncel, Jean-François Garnier and Céline Léandri-Bressy, "A map and a database for flint-bearing formations in Southern France: A tool for Petroarchaeology », PALEO [Online], 24 | 2013, Online since 15 September 2015, connection on 07 July 2020. URL : http://journals.openedition.org/paleo/2864 ; DOI : https://doi.org/10.4000/paleo.2864

This text was automatically generated on 7 July 2020 .

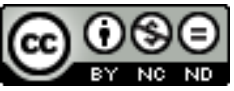

PALEO est mis à disposition selon les termes de la licence Creative Commons Attribution - Pas d'Utilisation Commerciale - Pas de Modification 4.0 International. 


\section{A map and a database for flint- bearing formations in Southern France: A tool for Petroarchaeology}

Une carte et une base de données pour les formations à silex du sud de la France: un outil pour la pétroarchéologie

Paul Fernandes, Jean-Paul Raynal, Pascal Tallet, Christophe Tuffery, Michel Piboule, Micheline Séronie-Vivien, Marie-Roger Séronie-Vivien, Alain Turq, André Morala, Jehanne Affolter, Dominique Millet, Françoise Millet, Fréderic Bazile, Patrick Schmidt, Pascal Foucher, Vincent Delvigne, Jérémie Liagre, Stéphane Gaillot, Alexandre Morin, Marie-Hélène Moncel, Jean-François Garnier and Céline Léandri-Bressy

\section{Introduction}

1 The necessity to determine the source of the raw materials used for tool making goes back to the earliest research in prehistory (Damour 1865). This type of approach is often biased by a lack of knowledge of the mineral domain exploited by prehistoric groups. It can also be difficult to assemble, harmonize, exchange and disseminate usable databases. This article presents an example of a supraregional and multidisciplinary approach aimed at developing a reliable tool for the reconstitution of procurement geo-domains.

\section{Persistent methodological difficulties}

Archaeopetrography is generally conducted on a local or a regional scale. The relevance of this discipline is based on the regional, or more rarely, extra-regional knowledge of raw material availability. Administrative limits are often inadequate for archaeological questions related to the movement of prehistoric groups and raw materials. Reference collections present disparate degrees of completeness in different 
regions. The lack of contact between prospectors is blatant, leading to the compartmentalization of the discipline and resulting in distorted issues and vocabulary. Generally speaking, data are not comparable as they are obtained through different acquisition protocols.

In the absence of a truly unitary approach called for by some researchers (Turq 2005), it is vital to reinforce collaboration between those involved in archaeopetrography in order to set up real information platforms. The prospecting of deposits is never exhaustive and we do not adhere to the approach recommended by Primault (2003), which represents inventoried deposits in a limited geographical zone. Moreover, the geological diversity of flint formations requires a detailed geological description for the context of each outcrop. In archaeopetrography, it is essential to combine this information with the description of the collected flint as this provides us with enhanced knowledge of the raw materials.

\section{The origin of the project}

4 The first maps were developed following the protocol defined in 2007 (Bressy et al. 2007), based on data collected during prospecting carried out by members of the PCR "réseau de Lithothèques en Rhône-Alpes": Affolter (Bauges, Bornes, Bugey, Jura, Mid Pre-Alps, Savoie, Vercors); Morin and Cousseran (Buech Valley); Bressy (Bauges, Buëch, Bugey, Chartreuse, Chambaran, Diois, Isère Valley, Royans, north Vercors); FéblotsAugustin Bugey, Ain); Valence CAP, Beeching and Brochier (Marsanne and Valdaine, Tricastin, Rhône Valley, south Baronnies); Bintz (Chartreuse, Diois, Isère, Vercors); Grünwald (Vercors, Royans, Isère, Diois, Chartreuse, Bugey); Fernandes (Auvergne, Cruas, Rochemaure, Saint- Montant, Saint-Marcel-d'Ardèche, Barjac-Issirac, LavalSaint-Roman, Carsan, Vans, Aubenas, Crest, Taulignan); Masson (Jura, Savoie); Picavet (south Vercors); Piboule (Auvergne, Loire, Cruas, Barjac-Issirac, Laval-Saint- Roman); Raynal (Haute-Loire), Riche (Vassieux); Vilain (Buggey, Savoie). These georeferenced data used different systems of coordinates (Lambert 2 zone, extended Lambert 2, WGS 84) which required standardization.

Once they were synchronized, these data were used to visualize sample points in the Rhône-Alps and Auvergne regions. The first trials were carried out as part of thematic prospecting in Auvergne and Languedoc-Roussillon (Lozère) in 2003 and then extended to Ardèche. They were linked to the study of the origin of the flint used in the sites of Saint-Anne I, Baume Valley and Payre. The results of these trials convinced us that a more ample comparison of the archaeological series would enhance the isolated observations made at each site. For the early Middle Paleolithic, this approach enabled us to assess the question of relations between the Rhone Valley and the Massif Central. The quality and quantity of the acquired documentation became sufficient to develop a model that went beyond regional geographical limits.

The maps obtained during this stage enabled us to visualize the topographic location, the stratigraphic origin and the secondary position of the outcrops. During the first three years, this GIS was mainly devoted to archiving geological information, but this was insufficient.

7 The representation of the outcrops as dots was exact, but only partially recorded the extension of the formations containing the mineral resources and comprised even less 
information regarding the complexity of their dispersal (or distribution) areas. Moreover, the widely-used regional scale was poorly adapted to the required level of precision.

8 From 2009 onwards, we thus concentrated on a mode of georeferencing based on the representation of formations. This new approach enabled us to merge data from several maps (Guibert 2000; Affolter 2009; Affolter and Bressy 2009; Bressy 2009...), which had not been possible with a system based on the representation of each outcrop.

In 2011, we decided to extend the field of our investigations to the whole of the South of France in order to address the problems raised by the presence of flint from distant outcrops (more than $100 \mathrm{~km}$ ) in the archaeological series. The new map indicates topographic limits and the stratigraphic origin of the main flint formations in six regions (Aquitaine, Auvergne, Languedoc- Roussillon, Midi-Pyrénées, Provence-Alpes Côte-d'Azur, Rhône-Alpes) (fig. 1).

Figure 1 - Flint formations map of the south of France. Scale 1/3000000.

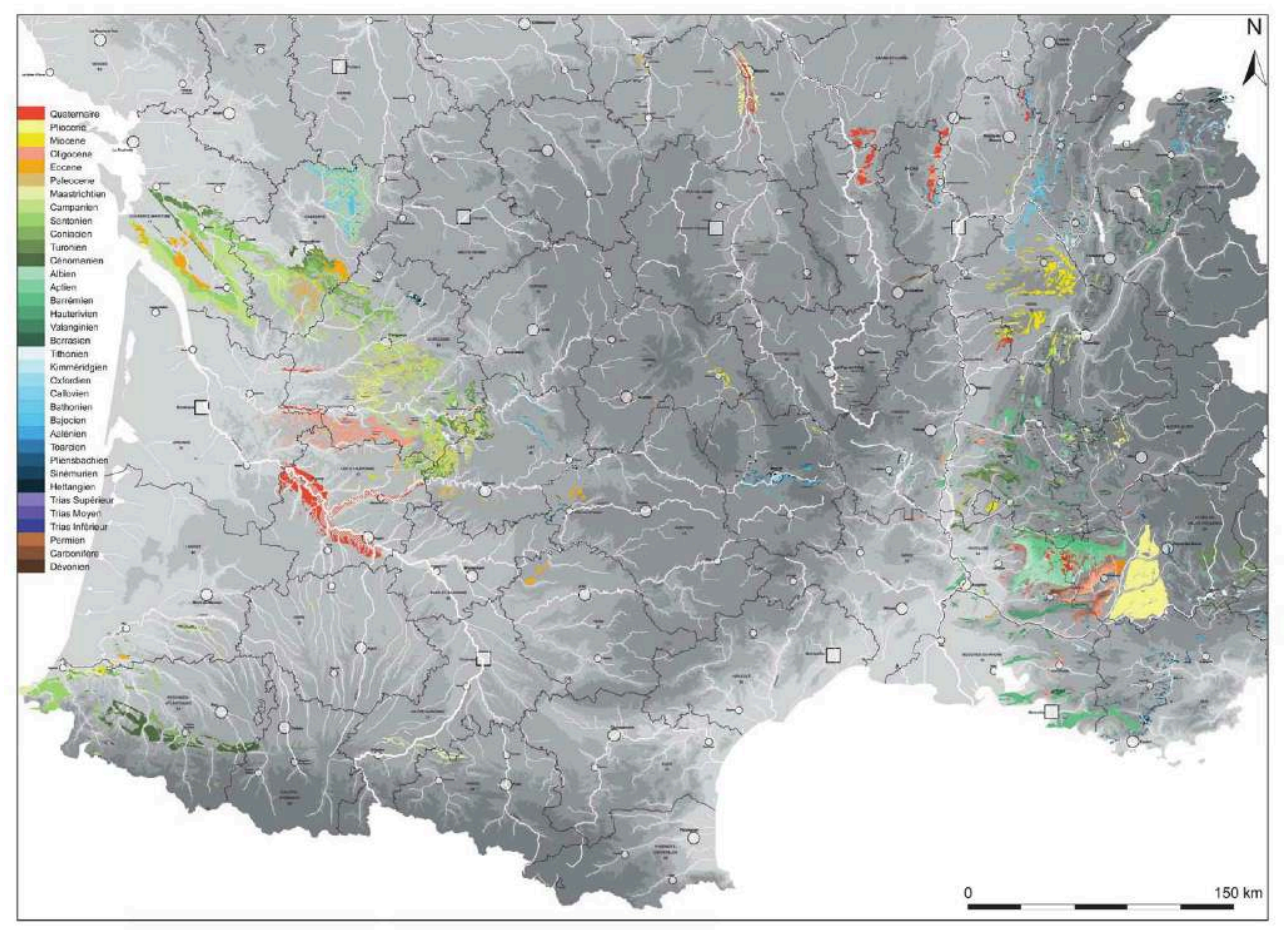

For the time being, our knowledge, our possibilities of access to the data and the developed network do not allow us to process the whole national territory. Our map is demarcated in the north by a straight line linking La Rochelle to Bourg-en-Bresse. This partition corresponds to the sectors for which we accumulated sufficient field data. The map is not comprehensive: a third of the surface in question is awaiting completion, which will only be possible with the participation of new researchers.

11 The system of cartographic coordinates used is the extended Lambert 2. This system was adopted for the following reasons:

- validity of the system for the whole of mainland France;

- possibility of projecting coordinates from all origins with the ArcGIS system; 
- possibility of superimposing transformed data with the IGN files BD ALTIÒ at $50 \mathrm{~m}$ in ArcGIS 9.2;

- possibility of superimposing projected data from the scanned BRGM 1/50 000 maps with ArcGIS 9.2;

- possible direct viewing of data in 3D/2D with ArcGIS Explorer 900.

\section{Conception of a renewed map} regional scale between different partners, most of whom are involved in the sourcing of archaeological flint (Jean-Paul Raynal, Roger Séronie-Vivien, Michel Piboule, Alain Turq, André Morala, Jehanne Affolter, Pascal Foucher, Fréderic Bazile, Dominique and Françoise Millet, Vincent Delvigne, Marie-Hélène Moncel, René Liabeuf, Céline Bressy, Jean-Pierre Platel). It is the outcome of prolonged teamwork and systematic or targeted prospecting (in Auvergne, Rhône-Alpes, Provence Alpes-Côte-d'Azur, Aquitaine, PoitouCharentes and Midi-Pyrénées) as well as the scrutiny of numerous documents. Besides the information collected directly from our partners, the program includes articles, thesis, monographs, PT and PCR reports, in conjunction with the analysis of 529 geological maps at 1/50 000 and their explanatory leaflets and 252 BSS Info Terre files which provide access to substantiated descriptions of coring and logs.

The research protocol for flint formations is the same for each geological map. First of all, the known or studied sources are located on the map. Previous research is taken into consideration: maps with flint formations are already available and generally, maps with georeferenced sites are symbolized by dots. These procurement zones are thus identified on geological maps in order to accurately define the contours of formations containing raw materials. Secondly, each leaflet is studied by looking for previously described flint-bearing formations. The dynamic captions of the site Info Terre are also all reviewed as the standardization work launched by BRGM for the vectorization of the geological maps provides supplementary information.

We opted for a detailed representation of the formations, at the scale of the geological maps of $1 / 50000$. In this way, the quality of the geological data is preserved without data loss or simplification.

These new maps only illustrate polygons visualizing primary outcrops and formations in secondary position with no connection to the primary formation. These formations are differentiated according to their sedimentation environment as well as their stratigraphic and geomorphological location. First of all, they are represented in dynamic PDF format.

16 By moving the mouse over one of the recorded formations, it is possible to open a descriptive and explanatory section which will include photographs at three different scales once the database will be finished, in order to obtain a reliable identity profile for each facies. The map is sufficiently accurate to be able to zoom in at different scales, from $1 / 1000000$ to $1 / 25000$. Paper versions at different scales make it possible to visualize the mineral resources of the South of France just as easily as those of a specific sector, such as Audignon (Landes), for example (fig. 2). 
Figure 2 - Flint formations map of Chalosse and western part of Pyrénées. Scale 1/500000.

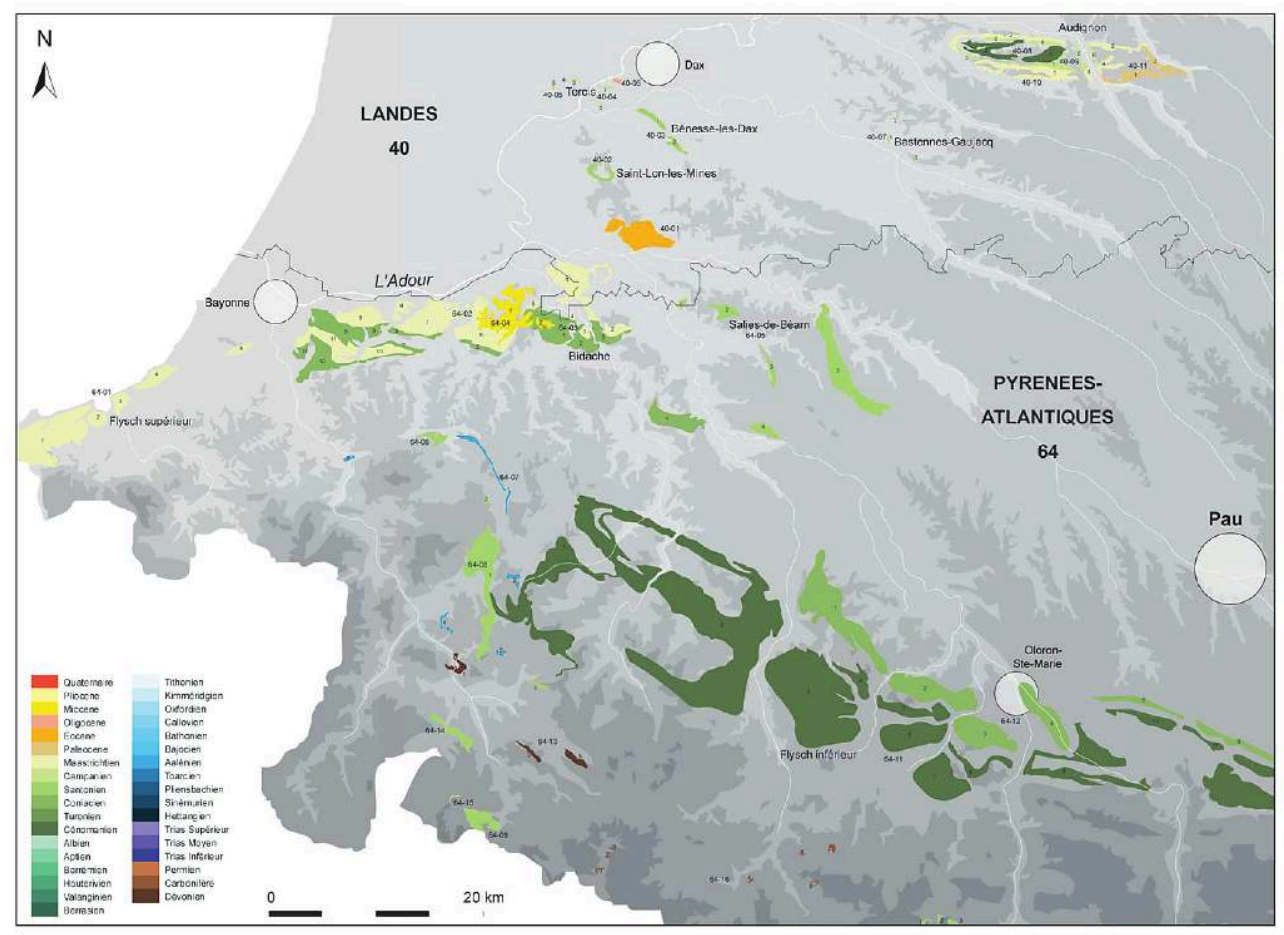

17 The name of the formations must have a descriptive value expressed by a term that accurately locates the geological entity in question. It generally refers to the nearest toponym on the 1/25 000 IGN map. For extensive formations, the official toponym of the largest administrative entity within the circumscribed zone is used. In exceptional cases and in order to facilitate comprehension, the chosen term must take account of those names previously used by archaeologists (in articles and monographs) or geologists (in map records): for example the Bergeracois designates flint issued from the final Campanian, present in the weathered rock around Bergerac.

The geological denomination of the formations is in keeping with the International Stratigraphic Chart ICS G. (Ogg 2010). The colours of the units partly respect the program of the geological map of France at 1/50 000 (2003). The problem of variability within the same geological stage has also been taken into account and is presented as a grid with variants whereby the stage preserves its standard colour.

The numbering has been simplified. It is not just the sampling points which are recorded but rather the whole of the flint-bearing formation with the same type(s) of flint. "The term formation designates in this way a site with similar characteristics that make up a complex and which can be judiciously further segregated" (Foucault and Raoult 1997).

Once the formation has been delimited, a three-digit number is attributed to it. The first two digits indicate the department, the following digits indicate the geographic location of the formation, which can have a dispersed distribution. In the case of a similar dispersed formation, we begin by numbering the formation located furthest south.

21 In the future, we will need to establish three layers of superimposable data. A first for the formations in which the flint is in primary position, a second for weathered rocks and slope deposits of colluviums and a third for all the alluvial formations. 
22 A cartography based on the position of present day formations must take account the evolution of the relief, which implies a geological study for each secondary site studied. Our experience shows that it is essential to take account of the evolution of the hydrographic network and of the catchment areas. The materials present in this type of fluvial formation show dynamic polarities (types of routes covered by the flint) in the distribution of genetic families (flint collected in primary position) and deposit variants (issued from the evolution of the genetic types). The reconstitution of the natural movements of each flint is thus an essential element of archaeopetrography.

It is important to note that the flint formations probably do not all contain exploitable raw materials, either because of the inaccessibility of the nodules, or due to the size of the elements (too small) or the broken nature of the rock. For now, the map is a simple representation of the potential mineral resources and not of the actual exploited flint resources.

All the information used to develop this new map was compiled and standardized in an open database. These data are currently in the process of being georeferenced.

\section{Inventory and iconographic basis associated with the cartographic representation}

Each of the recorded formations is associated with a description of the surrounding rock and the siliceous inclusions and type(s) of flint present. These leaflets recall the name and the works of those who discovered and worked on the characterization of the flint. They are written by one of the authors and revised by the other members of the workgroup.

In this section, we use the example of the data sheet established for the anticlinal Audignon formations (formations $\mathrm{n}^{\circ} 40-08,40-09,40-10,40-11$, fig. 2). This ripple is one of the most extensive in Aquitaine. The axis is approximately parallel to the Pyrenees. It spreads over a length of $28 \mathrm{~km}$ from Mugron in the east to Aire-sur-Adour in the west. Outcrops are rare as the Mio-Pliocene cover masks part of the Cretaceous. The centre of the anticlinal is made up of Albian, Cenomanian and Turonian marine deposits. Some of these stages contain flint. The Senonian outcrops around the edges. The Maastrichtian is more represented in the south and sporadically on the northen slope. This complex is considered to be the source of a unique lithological marker, that of "Chalosse flint with lepidorbioids", which was a major source of lithic raw materials for prehistoric groups from the early Paleolithic through to the Neolithic. Reworked deposits with abundant flint are concentrated on the sides of the structure and are thus issued mostly from Campanian and Maastrichtian deposits. The observation of the Campanian flint has not yet been completed.

\section{Details from the data sheet (Fernandes, Séronie- Vivien, Tallet):}

- 40-08 1-Audignon, 2-Brocas - c1-2 Cenomanian. Layers of Pilo: white to beige, more or less dolomitic limestone, sometimes containing siliceous inclusions.

-40-09 1-Bidaou-Lasserre (Audignon), 2-Labay (Hauriet),3-Becquerettes (Montaut), 4Haouriet (Banos, Audignon),5-cliffs of Daourat, 6-cliffs of Berdoulon (Eyres- Moncube) - c6 
Campanian. Layers of Pré-Marie: white limestone with flint. The Campanian begins with a Glauconitic horizon then the limestone contains bars of silicifications parallel to the stratification. The fauna contains echinoderms, lamellibranches, nodosariids and pithonellae. The flint contains a high concentration of uniaxial spicules. At the top, small numbers of orbitoid type foraminifera prefigure the Maastrichtian layers.

-40-10 1-Cazaoubidaou-Barrère-Dumes (Montaut, Doazit, Horsarrieu, Dumes), 2-HaurietMaisonnave-Larrivière (Hauriet, Montaut, Banos), 3-Piréou, 4-Hillon, 5-Pirette (EyresMoncube, Montsoué) - c7 Maastrichtian. Layers of Dumes: beige micritic limestones with rudists, foraminiferae, silica geodes, brown flint.

-40-11 1- Feuilleraie (Sarraziet), 2-left bank of the Bahus (Bahus-Juzanx) - e1 Danian (on the geological map). The layers of Arcet outcrop all around the edge of the Audignon synclinal. The top level, which is only preserved in the east, is made up of a recifal limestone with polyps, algae and echinids with some silicified zones. The faunal associations seem to indicate an upper Paleocene age (e2 Selandian?) slightly later than on the map.

For the Campanian, the stratigraphic reference section is near the village of EyreMoncube, to the east of Audignon. It is on the top of this formation that the silicifications appear. These are bars of several tens of metres parallel to the stratification. These flints contain spicules, fragments of echinoderms, lamellibranches and, like in the other Campanian formations in this zone, pithonellae. The presence of a large number of glauconite grains dispersed in a generally microcrystalline matrix is must be noted.

At the hamlet of Barrère (Horsarrieu), we collected flint corresponding to this description from the surface. These were regular nodules with an eroded neo-cortex. The original colour is grey, they become whitish and even blond during the course of alteration in secondary position. Their structure is homogeneous and they have a mudstone to wackestone type texture. The matrix is microcrystalline. Peloid forms are rare and do not exceed $20 \mathrm{~m}$. The intraclasts are not frequent (less than $10 \%$ ). They are angular and well sorted. The macrofauna includes bivalves, fragments of echinoderms and even ostracods. Spicules are frequent and bryozoans are very rare. We observe a predominantly planctonic fauna (radiolarians, Globotruncana, valvulinids); benthic forms are very rare and we did not observe any lepidorbitoids. Numerous rounded grains of glauconite are dispersed throughout the matrix, some of which are over 100 $\mathrm{m}$. In the same colluvium formation, we observe flint with more abundant benthic forms (lepidorbitoids, orbitoids, Lagenae) which are undoubtedly part of the Maastrichtian.

The beige Maastrichtian limestones with rudists further north at Dumes, Cazaoubidaou or Banos contain an association of microfauna with abundant benthic organisms, which have also been identified in the flint. The determination of the foraminiferae from the associated limestone formations was published by Neumann (1958) and Feinberg (1964). The authors cited: Lepidorbitoide socialis, L minor, Clypeorbis mamillata, Hellenocyclina, Siderolites calcitrapoides, S. vidali (fig. 3 and 4). 
Figure 3- Geo/ogical sample (Fernandes 2010), stereomicroscope photographs of flint from Audignon-Cazaoubidaou, sampled at the top of Neogene sand formations (geographic coordinates: longitude $=0^{\circ} 39^{\prime} 27^{\prime \prime} 0$, latitude $=43^{\circ} 42^{\prime} 51^{\prime \prime} \mathrm{N}$ ). Photographs P. Fernandes, CAD P. Tallet;

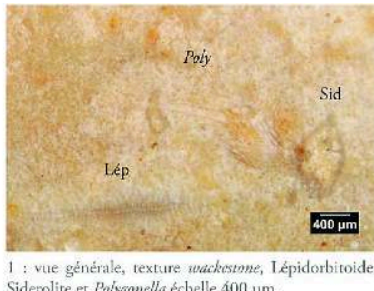

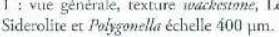

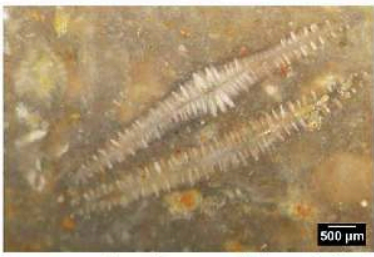

3: texture wackesestone à coupes méridiennes de Lépidorbiroides, échelle $500 \mu \mathrm{m}$.

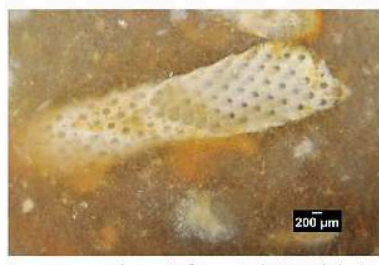

S: texure wadicstone à fragment de Dasycladacés (Cyindroporstle), échelle $2000 \mathrm{~mm}$
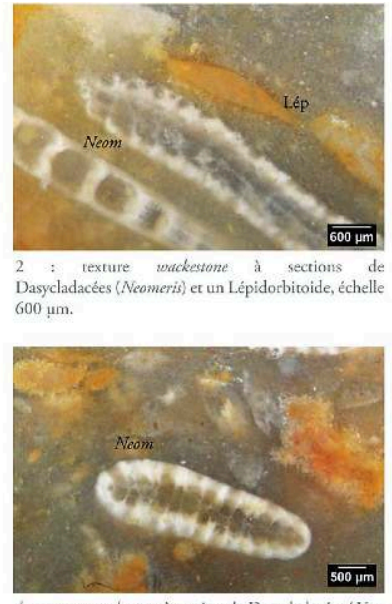

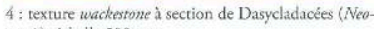
meris), échelle $500 \mu \mathrm{m}$.

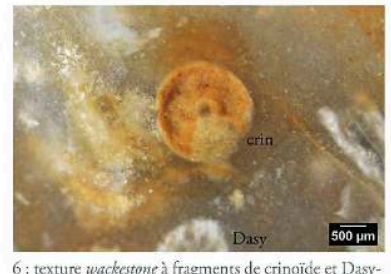
cadacées, echelle $500 \mu \mathrm{m}$

Figure 4- Geological sample (Fernandes 2010), stereomicroscope photographs of flint samples in the weathered levels at the top of the Maastrichtian at Audignon-Dumes (geographic coordinates: longitude $=0^{\circ} 35^{\prime} 34^{\prime \prime} 0$, latitude $=43^{\circ} 42^{\prime} 34,4^{\prime \prime} \mathrm{N}$ ). Photographs: P. Fernandes, CAD: P. Tallet

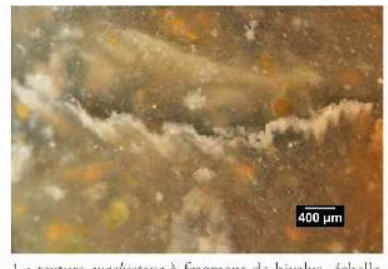

thesitonic à fragment de bivalve, échelle

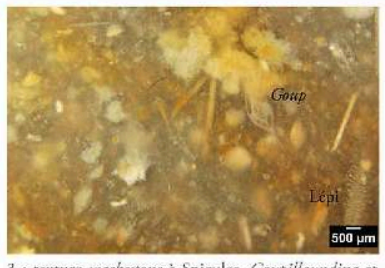
3: texture wathestone à Spicules, Goupillatudina c Lépidorbitoides, échelle $500 \mathrm{um}$.

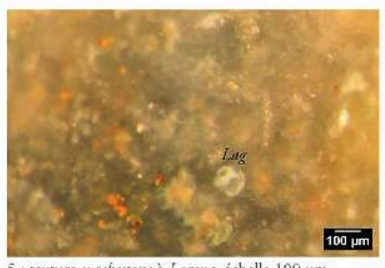

$\longdiv { 1 0 0 \mathrm { um } }$

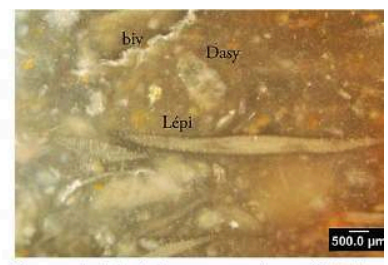

2: vue générale de la rexture wackestonè à Lépidorthide, bivalve et Dasycladacée (Neomerisis), échell

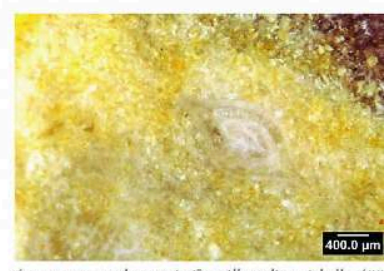

4: texture wackesstone à Goupillatundina, echelle 40 $\mu \mathrm{m}$

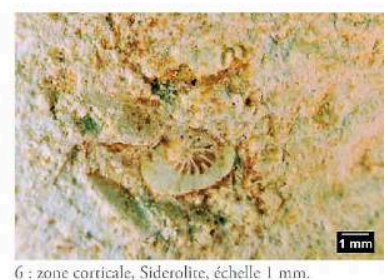



but some of them are over $40 \mathrm{~cm}$. In primary position the nodules bear a thick and chalky cortex. The flint was originally grey, but becomes brown rather quickly when it is in sub-primary (near the primary position) and secondary position. It is frequently patinated as the majority of the studied samples come from Miocene sands and particularly from sectors with ferruginous incrustations. Most of the flint sources present on the Audignon anticlinal are thus sub-primary and secondary sources supplied by the dismantling of Campanian and especially Maastrichtian limestones.

The samples collected by us in 2010 correspond to these descriptions. The structure is uniform and sometimes bioturbated. The texture is of wackestone type. The matrix is microcrystalline to cryptocrystalline. Peloid forms are abundant. Their size oscillates between 10 and $20 \mathrm{~m}$. The intraclasts represent less than $10 \%$ of the matrix. They are angular and rarely over 200. Bioclasts are abundant and represent $20 \%$ of the featured elements. The macrofauna includes fragments of bivalves, ostracods and echinoderms.

Spicules are represented in varying proportions. Bryozoans are rare or abundant depending on the facies. But the major difference in relation to previously described types is the over-representation of benthic forms in comparison to planktonic forms. All these elements point towards the definition of an internal platform, open to oceanic influences (presence of planktonic forms). We identified very rare pithonellae in some of the samples.

\section{Conclusion and perspectives}

This cartographic and inventory work, at the scale of the South of France, represents the first part of the development of an appropriate tool for studying human behaviour in relation to raw materials. In the future, we will have access to considerable data concerning outcrops and standardized data sheets characterizing several hundred types of raw materials. The compilation of these descriptive data should result in the development of an atlas of microfacies. This collective approach provides the necessary basis for the development of inter-regional studies on the identification of territorial strategies. The gathering of documents and observations, rigourous sampling modes and the renewed protocol for diagnosis result in more accurate determinations of the position of materials, especially for superficial formations. In the medium term, the totality of the data will be incorporated into the georesources (with the help of a GIS) of the heritage Atlas http://atlas.patrimoines.culture.fr), in order to harmonize the cartography, explanatory sections and the microfacies data sheets in the databases.

In order to enhance our understanding of the problems raised by the interactions between Man and the environment, our program must go beyond the data compilation stage. We opted recently for a dynamic representation, where each primary source is presented in association with all the related superficial formations. On this third generation map, we give priority to the type of raw material and assemble all the outcrops presenting the same lithological facies. The map must represent the main primary and secondary flint sources as connected, rather than separate entities. This approach allows us to follow each type of flint, to visualize its natural dispersal, to fuse these data with the archaeological data and leads to a better definition of the gathering zones. 


\section{BIBLIOGRAPHY}

AFFOLTER J. 2009 - Les Douattes (Musièges, Haute-Savoie) : les séries magdaléniennes et aziliennes des fouilles Jayet et Pion (1999-2002) in : G. Pion et L. Mevel (dir.) La fin du Paléolithique supérieur dans les Alpes du nord et le jura méridional. Approches culturelles et environnementales. Projet collectif de recherche dirigé par Gilbert Pion. Mémoire de la Société préhistorique française, 50, 161-172 p.

AFFOLTER J. et BRESSY C. 2009 - les matières premières siliceuses : méthodes d'études et ressources In : G. Pion et L. Mevel (dir.) La fin du Paléolithique supérieur dans les Alpes du nord et le jura méridional. Approches culturelles et environnementales. Projet collectif de recherche dirigé par Gilbert Pion. Mémoire de la Société préhistorique française, 50, 143-159 p.

BRESSY C. 2009 - Approvisionnements en silex à l'azilien récent : le site de Gerbaix (SaintChristophe, Savoie) In : G. Pion et L. Mevel (dir.) La fin du Paléolithique supérieur dans les Alpes $\mathrm{du}$ nord et le jura méridional. Approches culturelles et environnementales. Projet collectif de recherche dirigé par Gilbert Pion. Mémoire de la Société préhistorique française, 50, 173-194 p

BRESSY C., ANDRÉ P., FERNANDES P., PIBOULE M., REY P.-J. 2007 - Réseau de lithothèques en Rhône-Alpes, rapport d'activités du Projet Collectif de Recherche, 105 p.

DAMOUR A. 1865 - Sur la composition des Haches en pierre trouvées dans les monuments celtiques et chez les sauvages, Comptes Rendus de l'Académie des Sciences, LXI, séances du 21 et 28 août 1865 : 1-13.

FEINBERG H. 1964 - Contribution à l'étude stratigraphique et structurale du dôme d'Audignon, Thèse de 3ème cycle, Université de Paris, $182 \mathrm{p}$.

FOUCAULT J. et RAOULT J.-F. 1997 - Dictionnaire de géologie. Masson, Paris, 4e édition, 324 p.

GUIBERT R. 2000 - Gestion des industries lithiques mésolithiques et néolithiques du Sud-Est de la France, Thèse de 3ème Cycle, Université Paris-I, 369 p.

NEUMANN M. 1958 - Révision des Orbitoïdes du Crétacé et de l'Éocène en Aquitaine occidentale, Thèse de 3ème cycle, Université de Paris, $382 \mathrm{p}$.

OGG J G. 2010 - Latest version (Sept. 2010) of the International Stratigraphic Chart. Copyright () 2010 International Commission on Stratigraphy chart produced by the ICS.

PRIMAULT J. 2003 - Exploitation et diffusion des silex de la région du Grand-Pressigny au Paléolithique, Thèse de doctorat, Université Paris X, 362 p.

TURQ A. 2005 - Réflexions méthodologiques sur les études de matières premières lithiques. 1 Des lithothèques au matériel archéologique, Paleo 17, p. 111-131.

\section{ABSTRACTS}

A map of the main flint bearing formations in the South of France is under construction. It will provide an essential basis to develop interregional studies about flint procurements and travels. It results from collaboration between actors involved in topic flint sourcing. It includes results of their systematic surveys and studies in six regions (Aquitaine, Auvergne, Languedoc-Roussillon, Midi-Pyrenees, Provence-Alpes - Côte d'Azur, Rhône-Alpes). Moreover, it includes a large number of associated data: i) The main papers and those dealing with flint bearing formations of 
southern France, ii) more than 200 records from the under-soil database BSS BRGM, which give access to logs or scanned documents iii) 529 geological maps at 1/50 000 and their leaflets. The map is organized in three superimposed layers : a map of outcrops or primary deposits, a map of surficial weathered formation and a revised map of alluvial formations. The map is available in two versions which are easily updatable : a PDF version and an interactive GIS version. In this document, every formation containing the same type (s) (s) of flint is taken into account and forms a mappable entity. Every listed formation is linked to a text which describes the parent rock and/or the type(s) of flint(s). These records contain descriptive and explanatory pictures at different scale (naked eye to microscopic scale). Geological and archaeological references complement every record. The final version will constitute an atlas. Archaeologists and geologists will find description sheets of every type of flint and bearing rock. They will help for analytical diagnoses (structure, texture and mineralogical composition).

Une carte des principales formations à silex du sud de la France est en cours de réalisation. Elle propose, à tous les préhistoriens, une base nécessaire au développement d'études interrégionales sur la circulation des silex. Elle est le fruit d'une collaboration entre des acteurs impliqués dans la problématique de caractérisation de la provenance des silex. Elle regroupe les résultats de leurs prospections systématiques ou ciblées dans six régions (Aquitaine, Auvergne, LanguedocRoussillon, Midi-Pyrénées, Provence-Alpes-Côte-d'Azur, Rhône-Alpes). Elle intègre, en plus, le dépouillement d'un grand nombre de documents : $i$ ) les principaux articles et thèses traitant des formations à silex du sud de la France ; ii) plus de 200 fiches issues de la base de données du soussol BSS du BRGM, qui permettent de visualiser des logs ou des documents scannés ; iii) 529 cartes géologiques à $1 / 50000$ et leurs notices. La carte est organisée en trois couches de données superposables: une carte des affleurements ou gîtes primaires, une carte des altérites et des formations superficielles remaniées et une carte des formations alluviales. La carte existera dans deux versions numériques aisément actualisables: une version dans un format PDF et une version sous la forme d'un SIG. C'est l'ensemble de la formation contenant le ou les même(s) type(s) de silex qui est prise en compte, le terme de formation désignant un terrain possédant des caractères communs et qui constitue un ensemble cartographiable. Chacune des formations recensées fait l'objet d'une notice simplifiée qui décrit l'encaissant et - le ou les - type(s) de silex présent(s). Ces notices descriptives et explicatives contiennent des photos à toutes les échelles (de la formation à l'échelle microscopique). Des références bibliographiques géologiques et archéologiques complèteront chaque notice. La version définitive de ces notices constituera un atlas. Les archéologues et géologues disposeront ainsi de fiches descriptives pour chaque type de silex et son encaissant. Elles serviront aux diagnoses analytiques (structures, textures et compositions minéralogiques).

\section{INDEX}

Mots-clés: pétroarchéologie, silex, carte, base de données

Keywords: petrography, chert, map, database

\section{AUTHORS}

\section{PAUL FERNANDES}

Paléotime, 272 rue du lycée Polonais, FR-38250 Villard-de-Lans - paul.fernandes@paleotime Université Bordeaux 1, sciences et technologies, UMR 5199 PACEA, Bât. B18, avenue des Facultés, FR-33405 Talence 


\section{JEAN-PAUL RAYNAL}

Université Bordeaux 1, sciences et technologies, UMR 5199 PACEA, Bât. B18, avenue des Facultés, FR-33405 Talence - jp.raynal@pacea.u-bordeaux1.fr

Departement of Human Evolution, Max Planck Institute for Evolutionary Anthropology, Deutscher Platz 6, D-04103 Leipzig, Allemagne,

\section{PASCAL TALLET}

Paléotime, 272 rue du lycée Polonais, FR-38250 Villard-de-Lans - pascal.tallet@paleotime.fr

\section{CHRISTOPHE TUFFERY}

INRAP (DST/SMQ) 7 rue de Madrid, FR-75008 Paris - christophe.tuffery@inrap.fr

\section{MICHEL PIBOULE}

Université Joseph Fourier Grenoble - piboulemichel@gmail.com

\section{MICHELINE SÉRONIE-VIVIEN}

125 avenue d'Eysines, FR-33110 Le Bouscat : rseronie@club-internet.fr

\section{MARIE-ROGER SÉRONIE-VIVIEN}

125 avenue d'Eysines, FR-33110 Le Bouscat : rseronie@club-internet.fr

\section{ALAIN TURQ}

Musée national de Préhistoire, 1 rue du Musée FR-24620 Les Eyzies-de-Tayac -

alain.turq@culture.gouv.fr

Université Bordeaux 1, sciences et technologies, UMR 5199 PACEA, Bât. B18, avenue des Facultés, FR-33405 Talence

\section{ANDRÉ MORALA}

Musée national de Préhistoire, 1 rue du Musée FR-24620 Les Eyzies-de-Tayac -

andre.morala@culture.gouv.fr

Université Bordeaux 1, sciences et technologies, UMR 5199 PACEA, Bât. B18, avenue des Facultés, FR-33405 Talence

\section{JEHANNE AFFOLTER}

UMR 5594 AR-GEO-Lab, Université Neuchâtel, Espace Louis-Agassiz 1 CH-2000 Neuchâtel affolterjs@bluewin.ch

\section{DOMINIQUE MILLET}

13 rue Bordas, FR-33400 Talence - prfmillet@orange.fr

\section{FRANÇOISE MILLET}

13 rue Bordas, FR-33400 Talence - prfmillet@orange.fr

\section{FRÉDERIC BAZILE}

Université de Montpellier 3, UMR 5140 « Archéologie des Sociétés Méditerranéennes », 3 route de Mende, FR-34199, Montpellier - fredericbazile@aol.com 


\section{PATRICK SCHMIDT}

Département de Préhistoire UMR 7194, Centre de spectroscopie infrarouge, CP 57, 57 rue Cuvier, FR-75231 Paris Cedex 05, France - patrick.schmidt@gmail.com

\section{PASCAL FOUCHER}

SRA Midi-Pyrénées, Hôtel des Chevaliers de Saint-Jean, 32 rue d'Albade, BP 811, FR-31080

Toulouse cedex 6 - pascal.foucher@culture.gouv.fr

\section{VINCENT DELVIGNE}

Université Bordeaux 1, sciences et technologies, UMR 5199 PACEA, Bât. B18, avenue des Facultés, FR-33405 Talence-v.delvigne@pacea.u-bordeaux1.fr

\section{JÉRÉMIE LIAGRE}

Service archéologique de la ville de Lyon, 10 rue Neyret, FR-69001 Lyon - jeremie.liagre@mairielyon.fr

\section{STÉPHANE GAILLOT}

Service archéologique de la ville de Lyon, 10 rue Neyret, FR-69001 Lyon stephane.gaillot@mairie-lyon.fr

\section{ALEXANDRE MORIN}

Paléotime, 272 rue du lycée Polonais, FR-38250 Villard-de-Lans - alexandre.morin@paleotime.fr

\section{MARIE-HÉLÈNE MONCEL}

Muséum national d'histoire naturelle - CNRS, UMR 7194 CNRS Département de Préhistoire, Institut de Paléontologie humaine, 1, rue René Panhard, FR-75013 Paris - moncel@mnhn.fr

\section{JEAN-FRANÇOIS GARNIER}

Société Préhistorique et Historique de Villeneuve-sur-Lot, BP 104, FR-47303 Villeneuve-sur-Lot CÉLINE LÉANDRI-BRESSY

Délégation Régionale à la Recherche et à la Technologie (DRRT) 66, Cours Napoléon, FR-20000 Ajaccio - celine.leandri@recherche.gouv.fr 